\title{
Research on the Integration of VR Virtual Technology into Ideological and Political Practice Teaching in Colleges and Universities
}

\author{
Liangxi Ding ${ }^{12}$ \\ ${ }^{1}$ Lyceum of the Philippines University Batangas \\ ${ }^{2}$ Nanchang Institute of Technology \\ ${ }^{*}$ Corresponding author. Email:282811170@qq.com
}

\begin{abstract}
Virtual reality (VR)technology has its unique advantages.The use of this technology in college ideological and political teaching can transform abstract theoretical knowledge into perceptible knowledge, which is helpful to realize the teaching effect of ideological and political courses. We explain the specific application of virtual technology in ideological and political teaching in colleges and universities through analysis and discussion, which will help us deepen the teaching reform of ideological and political courses.
\end{abstract}

Keywords: virtual technology; ideological and political teaching in colleges and universities; specific application

\section{INTRODUCTION}

Ideological and political courses in colleges and universities are theoretical, and the knowledge is relatively abstract. Therefore, abstract knowledge can be made more vivid and easy to be understood by VR technology, which will help improve teaching effectiveness [1].

\section{CONCEPTS AND ADVANTAGES OF VR VIRTUAL TECHNOLOGY}

As the name suggests, VR technology is to realize the integration of virtual and reality. On the aspect of theoretical, VR technology, as a computer simulation system, can build a new world and let people experience it. Also, it can simulate environment which is similar to reality by a computer, so that the user will immersed depth in the environment. VR technology makes extensive use of data in real life, forming electronic signals by using computer technology, realizing its integration with various output devices, and converting the signals into concrete images that can be perceived by people [2]. For these images, they are either real things in reality, or images constructed by threedimensional models that we cannot see with the naked eye. Since we cannot see these phenomena directly, they are a simulation of the real world using computer technology, so we call them virtual reality. More and more people begin to agree with VR technology. People can deepen their own experience and perception in the virtual reality world. The simulated environment has a high degree of similarity to the real world, which can be said to be difficult to distinguish. True or false, people will feel immersive in this environment. In addition, the virtual environment has a variety of perception functions, which are similar to human functions, such as vision, hearing, taste, touch, and smell perception systems. Finally, its simulation system is also very advanced, realizing Human-computer interaction. When humans operate in it, they can be random, and the virtual environment will also form real feedback on this. These advantages of virtual reality technology, such as multi-sensitivity, existence, and interactivity make more and more people start to love this technology. First of all, virtual reality technology has a feature of immersive, which is also the most important feature of virtual reality technology. In a virtual environment, people will think that they are already a part of the environment who are created by the computer, and the user's own perception function will be directly affects the depth of immersion of virtual reality technology. If the user has obvious perception of various stimuli in the virtual world, the resonance of thinking will appear, which will make a feeling of psychological immersion, 
as if people are in reality. Second, virtual reality technology has interactive features. The so-called interactivity refers to whether the user can freely operate the objects in the simulated environment, and whether the corresponding feedback can be obtained from the environment. After people enter the virtual space, through the corresponding technology, there will be mutual interaction between the user and the environment. If the user completes some operations, the corresponding reflection will also occur in the surrounding environment. For example, when the user makes contact with an object in the virtual space, the user's hand will react to the object. If the user makes some actions on the object, the state and position of the object will also change. Third, virtual reality technology has multi-perceptual characteristics. The so-called multiple perception means that computer technology has a variety of perception such as touch and smell, as well as hearing. For the ideal virtual reality technology, it has similar perceptual functions to that of humans. However, due to the limitations of some related technologies, especially sensing technology, most of today's virtual reality technologies generally have only a few perceptual functions: vision, hearing, touch, movement and so on. Fourth, virtual reality technology has conceptual characteristics. The so-called conception, we can also call it imagination, in virtual space, users and the surrounding objects can achieve interaction, their cognitive scope will be constantly expanded, which can be constructed for scenes that do not exist or can not exist in the real world. We can understand the idea as that after entering the virtual space, users can understand the knowledge according to their own feelings and cognitive ability, broaden their thinking, and then construct new environments and concepts.Fifth, the virtual reality technology has the characteristics of autonomy [3]. Autonomy refers to the movement of objects in a virtual environment, which will move according to the laws of physics. For example, when an external force is pushed, the object will change in the direction of the force.

\section{CURRENT SITUATION OF IDEOLOGICAL AND POLITICAL TEACHING IN UNIVERSITIES}

\subsection{Lack of reasonable curriculum, and the teaching mode is relatively single}

Nowadays, there are unreasonable phenomena in the courses set up in ideological and political education in colleges and universities. Generally, there are few hours when setting ideological and political courses, and the important position of ideological and political courses is not fully reflected in the curriculum [4]. Some schools even set ideological and political classes in evening selfstudy and weekends. In addition, the effectiveness of ideological and political education courses is insufficient, and there is not much attention to the hot spots and difficulties of college students ' attention and suspicious issues. When teaching courses, the teaching mode is relatively single, most schools still use the traditional indoctrination teaching mode, teachers ' teaching content is relatively outdated, lacking pertinence to reality, emphasizing its policy theoretical, while ignoring its practical side. Teachers are often alone in the classroom explaining, students are just a passive acceptance, the classroom atmosphere is not active, and there is a lack of interaction between teachers and students. This didactic teaching method can not arouse the enthusiasm of students for learning, so students' enthusiasm for learning is not high.

\subsection{Neglect of mental health education for college students}

Psychology believes that emotion, as an inner experience, mainly refers to a feeling brought about by whether people's needs can be met or not. In the ideological and political education of colleges and universities, the teaching method of instilling preaching is generally adopted.This mode ignores the students ' emotional experience. The classroom atmosphere lacks democracy and relaxation, and there is a lack of good interaction between teachers and students, so the atmosphere of the classroom is relatively dull, and the students ' learning enthusiasm cannot be stimulated. Students are only passive recipient in learning. In such a learning process, students ' emotional experience will be relatively poor, and happiness and pleasure cannot be effectively reflected, and thus they will not be able to deepen the knowledge they have learned, resulting in the lack of pertinence and effectiveness of ideological and political courses. In addition, ideological and political education in colleges and universities ignores the psychological problems of college students. In the process of education, colleges and universities attach great importance to management and results and ignore the education and process. We know that there are differences among students in terms of needs, interests, hobbies, levels of psychological development, and the ability to understand and accept. If you ignore this difference, it will cause big problems. In the process of growing up, the living environment of college students will change, and there will also be some psychological problems and psychological obstacles, such as emotional problems, interpersonal tension and inferiority. If these psychological problems cannot be solved timely and effectively, it will directly affect the future life and work and social interaction of college students. 


\subsection{Lack of information timeliness}

Traditional education methods are mainly based on long accumulation of information and then instilling it to students in lectures or classes. In the network environment, a large amount of information is spreading rapidly, which has caused fierce conflicts between a variety of values. This makes information management and control, as well as public opinion guidance and correction, and other network phenomena face huge challenges. In the Internet environment, the rapid and extensive dissemination of traditional education methods with delay effect and information has been seriously separated, and in the Internet application, young students have more advantages than teachers. In this way, traditional ideological and political education not only fails to guide students to fully understand party and government policies in terms of educational output, but also cannot be as vivid as the Internet in terms of educational effects, and thus cannot effectively guide students' ideological values [5]. In terms of ideological and political education, this represents the lack of the main body of the school. The school does not effectively guide students, which in turn makes students blindly accept all kinds of information and knowledge transmitted on the Internet, and ultimately affects students' ideological values.

\subsection{Lack of strong student participation}

The traditional way of education is a one-way indoctrination mode. Under the impact of the Internet, it lacks freshness in terms of thought and value guidance. As the audience of education, students will also lack enthusiasm in participating in ideological and political education. As far as the content of ideological and political education is concerned, schools and teachers are lagging behind in the education concept and value orientation, and there are many phenomena not in place [6]. When a major problem arises in society, many educators avoid it, and simply explain the teaching content of ideological and political education, and cannot be organically connected with various actual phenomena in society. Students are generally interested in these social issues and are willing to express their various opinions and views on them. The lack of contact between social focus issues in ideological and political education will make students lose their interest in learning and their right to express their views, so as not to meet their value needs for educational content, and then make them lack enthusiasm and initiative in participating in ideological and political education activities [6]

\subsection{Ideological and political quality of educators needs to be improved}

The goal of ideological and political education in colleges and universities is to develop college students 'life attitude towards a positive and healthy direction, improve college students' cultural quality and ideological and moral quality, and improve their ability to recognize and transform the world. After entering the society, college students can become the talents that the society really needs. Nowadays, some ideological and political educators in colleges and universities do not have high ideological and political qualities, lack firmness in political faith,lack a good sense of responsibility, do not invest all their energy in ideological and political education, and lack enthusiasm and enthusiasm in their work. Ideological and political teachers themselves cannot set a good example among the students, so that they cannot ensure the good results of ideological and political education.

\section{APPLICATION OF VR VIRTUAL TECHNOLOGY IN IDEOLOGICAL AND POLITICAL PRACTICE TEACHING IN COLLEGES AND UNIVERSITIES}

\subsection{Good teaching import by building a virtual scenario}

In the process of carrying out ideological and political course teaching, general teachers ignore the introduction link before class. When teaching, some teachers tend to ignore the introduction link, and they often directly enter the theme when teaching. At the beginning, the students ' attention was not concentrated enough, and their enthusiasm for class was not mobilized, so the teaching effect was not ideal. Therefore, based on such a situation, teachers can use virtual reality technology to construct the virtual teaching scene, import it before class, let students analyze and discuss this scene, and then teachers will naturally transfer to the formal course teaching. In this way, the introduction link of ideological and political course teaching will be more effective, and it will also stimulate students ' attention and interest in learning, so that students can better play their own enthusiasm in the subsequent classroom teaching activities [10]. For example, when teachers explain the inheritance and promotion of patriotic tradition and national spirit, they can construct a virtual reality scene, such as constructing a patriotic story in a virtual space, and let students learn about the patriotic spirit embodied in this scene in the classroom. Analyze and guide students to think about how to choose if they are the characters in the story. Enhancing the pre-class introduction through such virtual scenes will improve the teaching effectiveness of the entire classroom. 


\subsection{Deepen the teaching effect by constructing virtual scenarios}

In the teaching process, teachers can construct various scenes in history virtually. For example, when explaining the establishment of the Communist Party of China and the process of several historical revolutions completed by the party leaders, teachers can use virtual construction to make them in a virtual environment. The true restoration in this way can deepen the students' indepth understanding of the revolutionary process led by the Communist Party [7]. Teachers should let students know that, on the one hand, the social revolution in the overall sense of China is composed of revolution, construction and reform, which reflects the logical process and essence correlation of the Party and the people in the social practice of various historical stages. At the beginning of its founding, the Communist Party of China made clear provisions in the Party Constitution that "implementing social revolution is its fundamental political purpose". Later, it led the Chinese people to realize the new democratic revolution and enabled the establishment of a new China in which the people are masters of the country. In order to make the backward agricultural countries to achieve the goal of advanced industrial countries, the party led the people to carry out a the socialist revolution, adhere to the socialist system and explore the construction of socialist constantly, let our country's industrial system and the national economic system construction more independent and complete, on the basis of the experience and lessons of the socialist construction, the party led the great revolution of reform and opening up, created the road of socialism with Chinese characteristics. On the other hand, as the core of leadership of the social revolution, the Party should continue to carry forward its advanced nature and purity through self-construction, and then enhance the vitality of the political party, so as to lead the people to achieve various goals and ideals. In summary, the Communist Party of China can always let the people support, and lead the people to carry out revolution, construction and reforms. This is due to its high organizational and mobilization ability, self-repair ability and ideological style construction, it can timely adapt to the new situation, and realize the continuous renewal of self-renewal [8]. In addition, we sort out the 500 years of socialist development history and can find that the value care of the development of Marxist theory and the highest goal of our political party is to realize the free and comprehensive development of people and establish the ideal society of human liberation. The history of the Party has fully proved that the process of the Party's struggle is to realize, safeguard and develop the fundamental interests of the overwhelming majority of the people. On the other hand, the people have realized and used and realized their main power and value. During the period of the new democratic revolution, the concentrated embodiment of the people giving full play to their main power was to participate in and support the revolutionary war. Since its establishment, the People's Republic of China has effectively ensured the master status of the people through the formulation of the national system and legal system, and has also allowed the people to continue to increase their enthusiasm for building socialism, especially in the new stage of reform and opening up. It has given full play to its spirit of reform and innovation, and has greatly improved in terms of material and cultural life.

Marx, Engels and other sages have passed away. Although students cannot have a real dialogue with them, teachers can use computer systems for virtual simulations to achieve the ideal effect, so that students ' learning needs can be met. Through virtual technology, students can "travel" back to the war years, feeling the atmosphere of war, deepening their understanding of the revolutionary course of the party leaders, and allow students to "dialogue" with sages such as Marx, Engels, and Mao Zedong. In this way, it can arouse students' enthusiasm for learning, and also make students like to participate in political life and love the learning of ideological and political courses.

\subsection{Better present the knowledge connotation by constructing a virtual scene}

General Secretary Xi Jinping pointed out that in carrying out ideological and political education, we should firmly grasp the theme, mainstream and essence of the Party's historical development, and schools should also follow this principle when carrying out ideological and political education. The basic process of the CPC's leadership and exploration of the cause of socialism with Chinese characteristics is also a process of continuous exploration of theories, roads and system of socialism with Chinese characteristics. This requires educators to use more creative thinking and adhere to the principle of seeking truth from facts, to accurately analyze correctness and error, mainstream and tributary, essence and phenomenon, and achieve the organic combination of historical theory. Take the principles and methods of historical materialism to guide the students, so that they can deeply understand the development trend of history, analyze various historical phenomena, further clarify the mainstream and tributaries of history, and distinguish the essence and phenomenon of history. When understanding and evaluating historical figures and events, we should make a realistic evaluation based on their specific spatial and temporal environment [11]. We must pay attention to the overall analysis to prevent the one-sided exaggeration of the setbacks in historical exploration, let alone generalize. To understand the twists and turns in the process of history, and to understand the contingency in the historical necessity. Ideological and 
political education should not only list the historical materials and description process, nor should it go from concept to concept, but to realize the organic combination of historical materials and theory.

Teachers can use virtual technology to construct virtual historical scenes. For example, for the situation of enemy sweeps during the Anti-Japanese War, they can construct such scenes, allowing students to experience the roles of ordinary people and Eighth Route Army fighters, and bring in different roles respectively, let students feel and think, so that students will have a deeper understanding of patriotism and a deeper understanding of the abstract knowledge points in the classroom. In addition, ideological and political education itself is a historical reference system to observe the social reform of the Communist Party of China and China. It explains the basic course of the governance of the CPC from the perspective of the development of New China, promoting reform and opening up and the exploration of socialism. This requires us to have the vision and pattern of "big historical view", and through scientific horizontal and vertical comparison, can we explain the development miracle of China. In the horizontal aspect, for the revolutionary practice of China's national liberation, we can compare it with the independent practice of the broad number of countries in Asia, Africa and Latin America, and explain the unique course of the Chinese revolution through the superiority of the stability and the organizational power of the national regime. In the vertical aspect, we can also compare the old China and the new China, explain the development achievements from the revolution and construction and reform, and clarify the party advantages that the Communist Party of China keeps pace with The Times. Through virtual technology, the teacher can build the process of our country and society through virtual scenes, and let students "participate" to feel this change, which is no longer a kind of abstract knowledge, and students will also deepen their understanding in the "participation" scene. On the perspective of history, ideological and political education and teaching need to establish a global vision, not only to compare China's historical development path with other countries and regions' history, but also to see the Chinese nation stand up and rich and strong in the three historic leap changes, and the impact on the world pattern and the international order, so as to let students from the whole to deepen the understanding of a century [9]. In virtual scenarios, these horizontal and vertical diachronic and synchronic scenarios can change at any time, and through different switching, they can deepen students ' cognition of the horizontal and vertical contrast results.

\subsection{Influence of Virtual Reality Technology on Ideological and Political Education in Colleges and Universities}

First of all, for the traditional ideological and political education courses, the knowledge and theories generally taught are relatively abstract. By using virtual reality technology, these abstract knowledge can be made real and tangible, and historical scenes can be restored to today. Let students immersed in it to feel and experience, which can improve students ' enthusiasm, the learning of knowledge is no longer rote, and the learning effect is more ideal [12]. Secondly, from the perspective of teachers, teachers can use virtual reality technology to reduce their management burden and time cost; at the same time, they also put higher requirements for ideological and political teachers. Teachers in the new era Teachers in the new era should integrate skills and theories organically and become all-round teachers, not just "teachers" and "plagiarist" in the traditional sense.

\subsection{Lack of Virtual Reality Technology in Ideological and Political Education and Teaching}

First of all, colleges and universities still lack the corresponding management technology, which makes the later macro-management and micro-supervision face some challenges. If students do not have good local selfmanagement ability, the predetermined goals cannot be achieved. Secondly, various modeling techniques and scene rendering techniques have high production costs. Due to some limitations of optical fiber optic equipment, virtual imaging technology does not yet have a high resolution, so it cannot be promoted quickly. Finally, the rendering resolution of the light effect and the intensity of the light, if there is a lack of optical management, will make the retina damage, multiple space display will also let the students appear the problem of improper refractive index, and long-term wear will cause problems such as eye damage[13]. Therefore, only through the supervision of the relevant national departments, and through a large number of tests of the curriculum teaching practice, and constantly enrich and develop the virtual reality technology in practice, can it provide better services for the ideological and political education and teaching in colleges and universities.

\section{CONCLUSION}

The use of virtual reality technology in ideological and political teaching in colleges and universities can improve the teaching effect, and improve students 'enthusiasm and enthusiasm for learning, and then promote the good development of ideological and political teaching in colleges and universities. Teachers 
should improve their comprehensive skills in specific teaching, use more virtual technology, improve students' interest in ideological and political courses, and finally realize the teaching goals of ideological and political courses.

\section{AUTHORS' CONTRIBUTIONS}

In 2020, the humanities and social sciences planning project of colleges and universities in Jiangxi Province: virtual practice teaching research of college ideological and political theory based on VR technology, obtaining phased research results, subject master: Ding Liangxi, subject number: JC20111

In 2020, Jiangxi Provincial Colleges and Universities Party Building Research Project Planning Project VR + Smart Party Building Position Mode Construction Research, obtaining phased research results, subject master: Ding Liangxi, subject number: 20DJYB049

\section{REFERENCES}

[1] Xu Ling, Huang Bo. Application Advantages and Reality Foundation of Virtual Reality (VR) Technology into College Ideological and Political Courses Teaching [J]. China Journal of Multimedia and Network Teaching (journal), 2021 (02): 28-30.

[2] Meng Xiangyun. VR Technology Boosters the integration of the Spirit of Red Flag Canal into University Ideological and Political Theory Teaching [J]. Journal of Anyang Institute of Technology, 2021,20 (01): 20-22.

[3] Qin Rui. Analysis on the Value and Path of VR Technology in Ideological and Political Theory in New Era [J]. Beijing Education (Moral Education), 2020 (05): 62-65.

[4] Zhao Yiming, Zhang Jinliang, Jiang Dong, Zhao Ruihong, Liu Luyao, Xie Yujia. Research on the Innovative Mode of Integrating Red Tourism into University Ideological and Political Practice Course Based on VR Technology [J]. Think tank Age, 2020 (11): 46-48.

[5] Fu Kun. Practice Teaching Base Construction in Colleges and Universities - Taking Anhui Vocational and Technical College of Mining as an example [J]. Journal of Inner Mongolia University of Finance and Economics, 2020,18 (02): 34-37.

[6] Liang Jun, Chen Lijiao. Influence of Virtual Simulation on Ideological and Political Theory - Based on SWOT Analysis [J]. Higher Forum, 2018 (03): 5-7.

[7] Guo Cuicui, Wang Shuangli. The core values of socialism are in the reform of "Curriculum
Ideological and Political" The value guidance and integration path in the revolution-Based on "College Students' Mental Health Education

"Lesson" as an example[J].Journal of Hubei University of Economics (Humanities and Social Sciences Edition),2020,17(12): 138-141.

[8] Mana. Xi Jinping's New Era Socialism Thought with Chinese Characteristics and College Thinking Research on the Integration of Political Courses- Taking Xinjiang Agricultural University as an example[J].Modern Business and Trade Industry,2020,41(34):123-124.

[9] Cheng Suyu. Practical exploration of the "10 Ones" teaching mode of ideological and political courses in higher vocational colleges-Taking Shanxi Mechanical and Electrical Vocational and Technical College <Introduction> as an example[J] .Journal of Jincheng Vocational and Technical College, 2020, 13(06): 57-59.

[10] Yan Wenhua, Wu Shuxia. An analysis of the "cloud ideological and political" hybrid teaching method under the background of the MO classTaking the course of "Mao Zedong Thought and An Introduction to the Theoretical System of Socialism with Chinese Characteristics" as an example[J]. Journal of Mudanjiang University, 2020,29(11):99-101+121.

[11] Wang Yanhua. Innovative research on the teaching mode of ideological and political courses in colleges and universities based on the hot topic flipped teaching method-Taking "Introduction to the Basic Principles of Marxism" as an example[J ]. Journal of Yuzhang Teachers College, 2020, 35(05): 46-50.

[12] Wang Shengyu. General Secretary Xi Jinping's Three Questions about College Ideological and Political Teachers' "Sentiment Must Be Deep"Taking Online Live Demonstration Class Teaching of Marxism School of Anhui Normal University as an example [J]. College Counselor Journal, $2020,12(05): 1-6$.

[13] Deng Ruoyu, He Ling, Zhang Jing. Research on the Integration of Social Practice and Structural Integration of Ideological and Political Classroom Connotation in Colleges and UniversitiesTake the course "Introduction to Mao Zedong Thought and the Theoretical System of Socialism with Chinese Characteristics" Teaching as an example[J].Journal of Shanxi Energy University,2020,33(05):32-35. 